\title{
Management of Intraductal Papillary Mucinous Neoplasms: Controversies in Guidelines and Future Perspectives
}

IJM Levink, $M D^{*}$

MJ Bruno, MD, PhD

DL Cahen, MD, PhD

\author{
Address \\ *Department of Gastroenterology and Hepatology, Erasmus University Medical Centre, \\ Floor Na-6, Doctor Molewaterplein 40, 3015 GD, Rotterdam, the Netherlands \\ Email: i.levink@erasmusmc.nl
}

Published online: 8 September 2018

(C) The Author(s) 2018

This article is part of the Topical Collection on Endoscopy

Keywords Pancreatic cyst $\cdot$ Intraductal papillary mucinous neoplasm $\cdot$ IPMN $\cdot$ Management $\cdot$ Guideline $\cdot$ Diagnosis

\begin{abstract}
Purpose of review Management of intraductal papillary mucinous neoplasm (IPMN) is currently based on consensus, in the absence of evidence-based guidelines. In recent years, several consensus guidelines have been published, with distinct management strategies. In this review, we will discuss these discrepancies, in order to guide treating physicians in clinical management.

Recent findings The detection rate of pancreatic cysts has increased substantially with the expanded use of high-quality imaging techniques to up to $45 \%$. Of these cysts, $24-82 \%$ are IPMNs, which harbour a malignant potential. Timely detection of high-risk lesions is therefore of great importance. Surgical management is based on the presence of clinical and morphological high-risk features, yet the majority of resected specimens appear to be low risk.

Summary International collaboration and incentive large-scale prospective registries of individuals undergoing cyst surveillance are needed to accumulate unbiased data and develop evidence-based guidelines. Additionally, development of non-invasive, accurate diagnostic tools (e.g. biomarkers) is needed to differentiate between neoplastic and nonneoplastic pancreatic cysts and detect malignant transformation at an early stage (i.e. high-grade dysplasia).
\end{abstract}




\section{Introduction}

Intraductal papillary mucinous neoplasm (IPMN) is a pancreatic cystic lesion originating from intraductal growth of mucin producing cells. In 1980, Ohhashi et al. [1] were the first to describe IPMN. In 1996, it was recognised as a separate entity $[2,3]$. The increased detection and awareness of
IPMNs led to the development of several, mainly consensus-based, periodically revised national and international guidelines $[4 \bullet, 5 \bullet, 6 \bullet, 7 \bullet, 8 \bullet, 9 \bullet$, $10 \bullet$. Notably, evidence is mainly based on surgical cohorts and information on patients managed conservatively is limited.

\section{Classification}

Based on localization and extent, three subtypes can be identified; main-duct (MD-IPMN), branch-duct (BD-IPMN) and mixed-type IPMN (MT-IPMN). Every subtype exhibits a certain risk of malignancy and requires a specific therapeutic approach.

MD-IPMN is recognised as dilation (segmental or diffuse) of the main pancreatic duct (MPD) of $>5 \mathrm{~mm}$, for which other causes of ductal obstruction have been ruled out, is mostly located in the pancreatic head (64-67\%) and accounts for $15-21 \%$ of the IPMNs [11-13]. It has the highest risk to exhibit malignant disease $(28-81 \%)[10 \bullet, 12-20]$. Therefore, an MPD diameter $\geq$ $10 \mathrm{~mm}$ is considered an absolute indication for surgical resection [10•, 21]. Approximately $70 \%$ of patients is symptomatic [22].

BD-IPMN is defined as a grape-like cyst $(>5 \mathrm{~mm})$ that communicates with the MPD $[12,13]$. It accounts for $41-64 \%$ of IPMNs and can develop multifocally throughout the pancreas, with a preference for the uncinate process $[11,12]$. BD-IPMNs have the least risk of malignant progression (7$42 \%)$, yet their multifocality (40\%) and high post-surgical recurrence rate $(7-8 \%)$ are insidious. Interestingly, it has not been proven that multifocality increases the risk of malignancy $[10 \bullet, 12-20,23,24]$. The indication for surgical resection depends on the presence of high-risk clinical and morphological features $[6 \bullet, 10 \bullet]$.

MT-IPMN meets both criteria of MD- and BD-IPMN and is seen in 22$38 \%$ of cases, of which $20-65 \%$ are malignant $[12,13,15,16,18,19,25-$

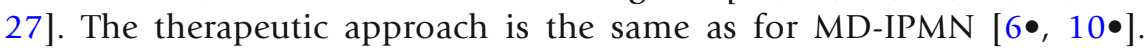
Potential overlap between these groups should be taken into account, since $29 \%$ of patients with BD-IPMN appear to have MPD involvement after resection [23].

IPMN is also classified according to its cellular morphology as gastric, intestinal, cholangio-papillary or oncocytic type. This classification is based on mucin (MUC) gene expression, architecture and cytology, yet different subtypes can be seen in the same cyst. Each type exhibits a particular risk of malignancy (Table 1).

\section{Risk factors}

Both the risk of IPMN development and malignant degeneration increase with age $[12,15,17,19,20,31]$. The mean age at time of IPMN detection is 65 years. 
Table 1. Characteristics of IPMN based on cellular morphology (data from surgical series) [28-30]

\begin{tabular}{|c|c|c|c|c|}
\hline & Gastric type & $\begin{array}{l}\text { Intestinal } \\
\text { type }\end{array}$ & $\begin{array}{l}\text { Pancreatobiliary } \\
\text { type }\end{array}$ & Oncocytic type \\
\hline Morphology & $\begin{array}{l}\text { Thick finger-like } \\
\text { papillae }\end{array}$ & Villous papillae & $\begin{array}{l}\text { Complex thin } \\
\text { branching papillae }\end{array}$ & $\begin{array}{l}\text { Complex thick papillae } \\
\text { with eosinophilic } \\
\text { oncocytic cells }\end{array}$ \\
\hline \multicolumn{5}{|l|}{ MUC gene expression } \\
\hline- MUC 1 & - & - & + & $-/+$ \\
\hline- MUC 2 & - & + & - & $-/+$ \\
\hline - MUC 5AC & + & + & + & + \\
\hline- MUC 6 & + & $-/+$ & $-/+$ & - \\
\hline Percentage of IPMNs & $46-63 \%$ & $18-36 \%$ & $7-18 \%$ & $1-8 \%$ \\
\hline \multicolumn{5}{|l|}{ Location } \\
\hline - Head & $69-72 \%$ & $64-67 \%$ & $63-67 \%$ & $25-33 \%$ \\
\hline - Body or tail & $28-31 \%$ & $33-37 \%$ & $34-37 \%$ & $67-75 \%$ \\
\hline Main-duct involvement & $19 \%$ & $63 \%$ & $50 \%$ & $38 \%$ \\
\hline Invasive progression & $10 \%$ & $40 \%$ & $68 \%$ & $50 \%$ \\
\hline Type of adenocarcinoma & Tubular $(79 \%)$ & Colloid > tubular & Tubular $(82 \%)$ & Tubular > colloid \\
\hline Mural nodules & $30 \%$ & $56 \%$ & $57 \%$ & $100 \%$ \\
\hline Recurrence rate & $9 \%$ & $20 \%$ & $46 \%$ & $14 \%$ \\
\hline 5-year survival & $85 \%$ & $85 \%$ & $54 \%$ & $79 \%$ \\
\hline
\end{tabular}

There is a small male gender predisposition [12, 19, 20]. Also, lifestyle is of influence, as smoking and alcohol abuse increase the risk of having high-risk and worrisome features $[11,31]$. Increased BMI and the associated presence of abdominal fat are known to play a role in the development of other pancreatic diseases (e.g. type-2 diabetes mellitus (DM) and pancreatic ductal adenocarcinoma (PDAC)), due to fatty infiltration and inflammation [32, 33]. Yet, knowledge about the relation between abdominal fat, IPMN and subsequent malignant transformation is limited. Sturm et al. (2013) [34] found a relation between severe obesity $(\mathrm{BMI} \geq 35)$ and an increased risk of malignant transformation in IPMN (OR 10.1, 95\% CI 1.30-78.32) [31, 35].

There is a causative link between IPMN and DM. Of patients with IPMN, $10-45 \%$ have diabetes $[11-14,16,19,31,36,37]$ and in the case of diabetes, the risk of detecting IPMN is higher (OR 1.79; 95\% CI 1.08-2.98) [35], especially in the case of insulin-use (OR 6.03, 95\% CI 1.74-20.84) [35]. In reverse, the presence of DM is associated with a higher risk of HGD (OR 2.02, 95\% CI 1.02-4.01) and carcinoma (OR 2.05, 95\% CI 1.08-3.87) [38]. Additionally, patients with chronic pancreatitis have an increased risk of IPMN (OR $10.1,95 \%$ CI 1.30-78.32) [31, 35].

Furthermore, having a family history of PDAC or another hereditary risk may pose a threat. Capurso et al. (2013) [35] compared 390 patients with IPMN with matched controls and found that $5.5 \%$ of the patients with 

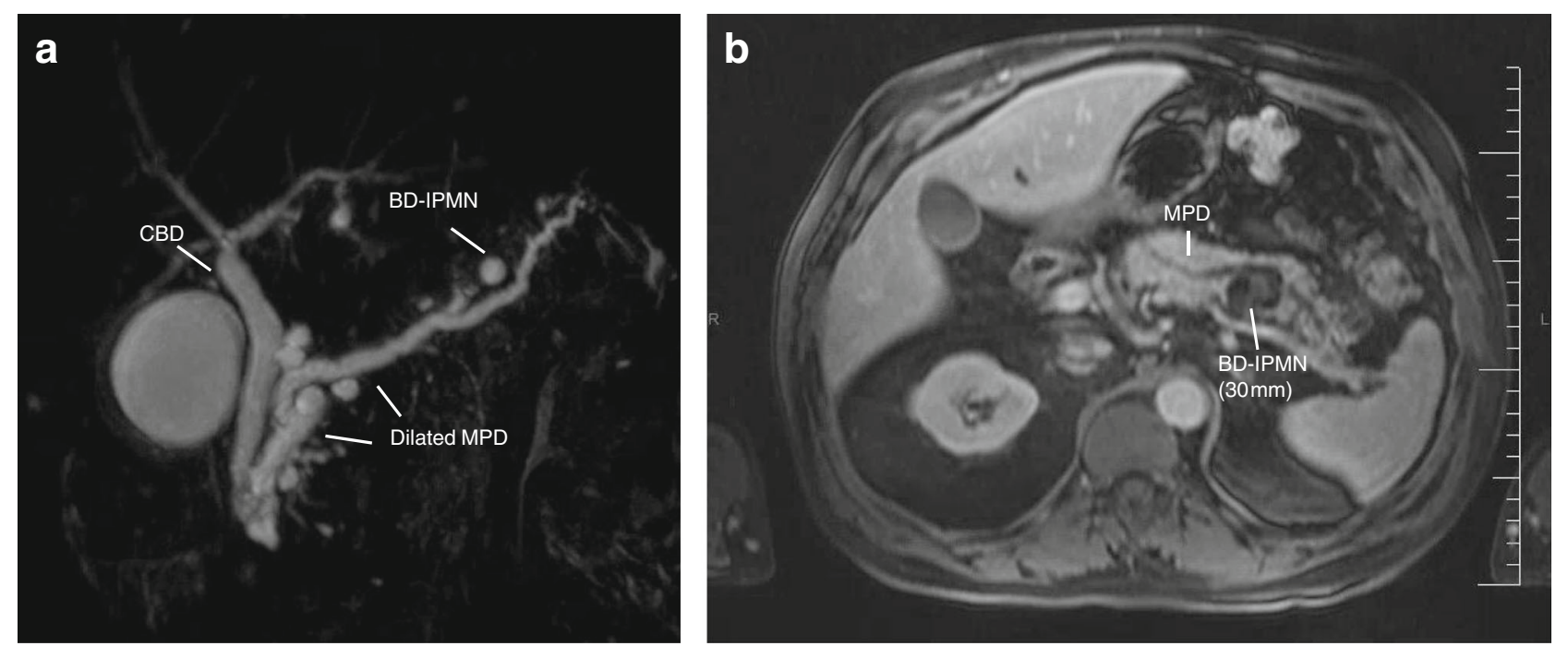

Fig. 1. a MRCP_diluted pancreatic duct and Santorini with distal a diameter of less than $1 \mathrm{~cm}$. Also, the image of multifocal small sidebranch IPMN. b MRI-ductus pancreaticus which is irregular at the level of the corpus and tail and is slightly dilated. Multiple cysteine deviations starting from the side duct. Largest cystic lesion located in the corpus with a staining solid component. Image matching a mixed-type IPMN with solid component as sign of a possible malignant degeneracy. PA—after pancreatic tail and spleen resection: the ductus pancreaticus and side branches show mixed-type IPMN, both gastric and pancreatobiliary type, with moderate dysplasia; there are extensive regressive changes with mucinous extravasation and fibrosis. No high-grade dysplasia, no malignancy

\section{Diagnosis}

IPMN and just $1.6 \%$ of the healthy controls had a 1 st degree family member with PDAC (OR 2.94 95\% CI 1.17-7.39 p 0.022) [31]. It is unknown whether patients with a positive family history have a more rapid progression. Currently, the management (surveillance and treatment), advised by clinical guidelines, is the same as for patients with sporadic IPMN [10•]. The Fukuoka guideline, however, recommends surveillance at 6-months' intervals in patients with a positive family history with operated IPMN [6•].

Most patients with IPMN are asymptomatic. Symptoms are associated with more advanced and invasive disease. Jaundice and abdominal pain are associated with invasive disease in 80 and $77 \%$ of IPMN cases, respectively. Of patients with IPMN, 13-32\% are reported to present with secondary acute (recurrent) pancreatitis, although this incidence is based on surgical series and likely to be overestimated. Other symptoms are weight loss, new-onset diabetes, steatorrhea and back pain [11-15, 17-20, 31, 37, 3941].

Currently, cross-sectional imaging plays a main role in lesion detection and differentiation. MRI (combined with MRCP) is the modality of choice, because of its superiority in cyst differentiation and identification of MPD connectivity, mural nodules, and septation. $[6 \bullet, 7 \bullet, 8 \bullet, 10 \bullet]$, as well as cyst 

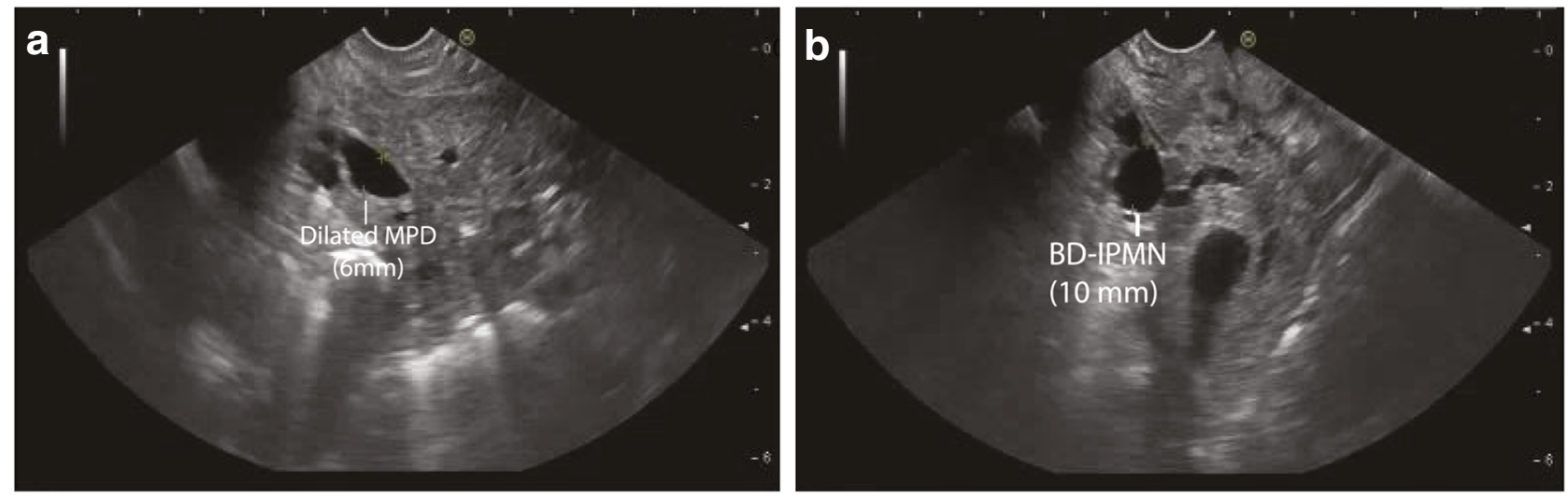

Fig. 2. $\mathbf{a}$ and $\mathbf{b}$ EUS screenshot captured from D2, the PD is continued from the papilla: focalized dilation over a short trajectory with a diameter of $6 \mathrm{~mm}$, slendering distally with a diameter of $2.7 \mathrm{~mm}$. There is a homogeneous 10-mm cystic lesion not far from the papilla with a connection to de PD. No murine nodule or wall thickening. Conclusion: mixed-type IPMN in pancreatic head and uncinate process

differentiation [42] (Fig. 1). Additionally, the repetitive nature of cyst follow-up mandates a non-invasive modality to eliminate radiation exposure $[6 \bullet, 10 \bullet]$. However, for identification of calcifications, tumour staging or surveillance of PDAC recurrence, addition of CT is recommended by some [10•]. Secretin injection during MRCP increases the likelihood of visualising MPD communication, yet only by $5 \%$. More studies are needed to determine whether the addition of secretin outweighs costs and prolongation of scanning time [43].

Endoscopic ultrasound (EUS) is a good alternative for imaging. It is mainly used to assess the presence of worrisome features and should not be performed in case of an established diagnosis or clear indication for surgery. Despite a low accuracy for differentiation between cyst types $(61-72 \%)[44,45]$, it is highly appropriate for the recognition and delineation of malignant characteristics, especially intracystic structures [46-48]. Addition of contrast increases the accuracy of mural nodule detection to 98\% [44] (Fig. 2).

An added benefit of EUS is that it allows for cyst fluid collection with fineneedle aspiration (FNA), which is indicated in case of indefinite imaging findings $[6 \bullet, 7 \bullet, 10 \bullet]$. The AGA recommends EUS-FNA in patients with a cyst diameter $\geq 3 \mathrm{~cm}$, solid component or dilated MPD [8•]. The Fukuoka guideline discourages FNA in case of either high-risk or worrisome features, out of fear for tumour spill [6•]. Cytological cyst fluid analysis has a high specificity $(91 \%)$, yet low sensitivity (65\%) for differentiation between benign and malignant IPMN [45, 49-51]. Sensitivity may be increased if the cyst wall and solid components are also sampled [54]. The risk of complications related to cyst EUSFNA is low $(0-2.5 \%)$, although higher than for solid lesions. Potential complications are abdominal pain, bacteraemia/infection, haemorrhage and pancreatitis. Prophylactic antibiotics are recommended [51, 55-59]

\section{Cyst fluid analysis and biomarkers}

A broad spectrum of tumour-specific (e.g. mutated KRAS and P53) and tumourassociated (e.g. CA 19-9) markers have the potential to distinguish high- from 
Table 2. Features suggestive for cyst-type and invasiveness [49, 58-67]

\begin{tabular}{|c|c|c|c|c|c|}
\hline Characteristic & Pseudocyst & SCA & MCN & IPMN & Malignant IPMN \\
\hline Age & $>40$ years & $>60$ years & $\begin{array}{l}\text { Young } \\
\qquad(\sim 40-50 \text { years })\end{array}$ & $>65$ years & $>65$ years \\
\hline Gender & $\mathrm{F}<\mathrm{M}$ & $F>M$ & $F>M(>95 \%)$ & $F \sim M$ & $F \sim M$ \\
\hline Symptoms & Regularly & Rare & Rare & Rare & Sometimes \\
\hline $\begin{array}{c}\text { Relation to acute } \\
\text { pancreatitis }\end{array}$ & Mostly & No & No & Sometimes & Sometimes \\
\hline $\begin{array}{l}\text { Relation to chronic } \\
\text { pancreatitis }\end{array}$ & Mostly & No & No & No & No \\
\hline Calcifications & No & $\begin{array}{r}\text { Sometimes } \\
\text { (central) }\end{array}$ & $\begin{array}{l}\text { Sometimes } \\
\text { (peripheral) }\end{array}$ & No & No \\
\hline Location & Not specific & Mostly distal & Mostly distal & Mostly proximal & Mostly proximal \\
\hline Connected to MPD & No & No & No & Yes & Yes \\
\hline Multifocality & No & Rare & No & Sometimes & Sometimes \\
\hline \multicolumn{6}{|l|}{ Serum } \\
\hline $\begin{array}{l}\text { Elevated CA19-9 } \\
(>37 \mathrm{U} / \mathrm{mL})\end{array}$ & - & - & $+/-$ & $+/-$ & ++ \\
\hline Mutated KRAS & - & - & - & - & ++ \\
\hline Mutated GNAS & - & - & - & + & $+/-$ \\
\hline \multicolumn{6}{|l|}{ Cyst fluid } \\
\hline Mucin & -- & -- & ++ & ++ & ++ \\
\hline $\begin{array}{l}\text { Amylase } \\
\qquad(>250 \mathrm{U} / \mathrm{mL})\end{array}$ & ++ & -- & - & $+/-$ & $+/-$ \\
\hline CEA & -- & -- & + & + & ++ \\
\hline Mutated KRAS & -- & - & + & + & ++ \\
\hline Mutated GNAS & -- & -- & - & ++ & + \\
\hline \multicolumn{6}{|l|}{ Pancreatic juice } \\
\hline CA19-9 & -- & - & - & $+/-$ & + \\
\hline CEA & -- & - & - & $+/-$ & + \\
\hline Mutated KRAS & -- & - & - & $+/-$ & + \\
\hline Mutated GNAS & -- & - & -- & ++ & $+/-$ \\
\hline SMAD-4/P53 & -- & - & -- & $+/-$ & ++ \\
\hline
\end{tabular}

low-risk lesions and guide decision-making (Table 2) [10•]. A perfect biomarker should be detectable in an early stage and specific for pancreas neoplasia. Apart from cyst fluid, other potential biomarker sources are serum and pancreatic juice.

Glycoproteins are often used as tumour markers. An increased serum level of CA19-9 $(>37 \mathrm{U} / \mathrm{ml})$ is found in $85 \%$ of the patients with PDAC and is used to follow the disease course [68]. For IPMN, it is an independent predictor of malignant transformation, with a (pooled) sensitivity 
and specificity of 40 and $89 \%$, respectively $[69,70]$. An increased serum CA19-9 level is a relative indication for surgery and supplementary diagnostics are recommended [10]. Cyst fluid CA19-9 levels have limited clinical value for the identification of advanced neoplastic disease, yet low CA19-9 levels $(<37 \mathrm{U} / \mathrm{ml})$ are suggestive for a non-mucinous origin [51]. Cyst fluid CEA is mainly used for cyst differentiation. A level of $<$ $5 \mathrm{mg} / \mathrm{mL}$ is highly specific (95\%) for a non-mucinous cyst and a value > $800 \mathrm{ng} / \mathrm{mL}$ for a mucinous cyst (95\%) [49]. Little is known about glycoprotein detection in pancreatic juice. Hirono et al. (2012) [58] found a high accuracy (92\%) for differentiation between benign and malignant IPMN, based on CEA levels in pancreatic juice (cut-off value $>30 \mathrm{ng} / \mathrm{mL}$ ) [58].

Mutated genes are released after cell death and have high potential to serve as biomarkers. Tissue GNAS mutations are associated with IPMN (5879\%; OR 30, 95\% CI 7.143-127.622), IPMN-associated adenocarcinoma $(36 \%)$ and mucinous carcinoma $(78 \%)$ [71-74]. In contrast, it is rarely detected in PDAC, PanIn-lesions and MCNs. The prevalence of GNAS mutations differs per morphological subtype: $100 \%$ in the intestinal type, $71 \%$ in the pancreatobiliary type, $51 \%$ in the gastric type and $0 \%$ in the oncocytic-type IPMN [75].

KRAS is the driver mutation in most pancreatic PDACs and is also detected in IPMN tissue (50\%; OR 7.4, 95\% CI 3.9-14.4) [74, 76]. However, it is less specific than GNAS, since KRAS is found in $69 \%$ of IPMN, $21 \%$ of MCN, $90 \%$ of PanIn-1 and 90\% of PDAC patients [74]. The presence of tissue KRAS and GNAS gene mutations is not related to IPMN location (BD-IPMN vs. MD-IPMN) [74]. In serum, Berger et al. (2016) [77] found that total circulating cell-free DNA levels of > $0.208 \mathrm{ng} / \mathrm{uL}$ distinguish between IPMN and healthy controls with 81\% sensitivity and $84 \%$ specificity, and between PDAC and healthy controls with $83 \%$ sensitivity and $92 \%$ specificity. More specifically for GNAS and KRAS, $71 \%$ of patients with IPMN harboured cell-free circulating mutated GNAS. Mutated KRAS was not detected in patients with IPMN, although it is present in $42 \%$ of patients with PDAC [77]. Adding molecular testing to clinical features and morphology increases sensitivity of IPMN and MCN differentiation to 90 and $94 \%$, respectively. However, more research is needed to distinguish whether the clinical value outweighs the high costs of these sensitive laboratory techniques [59, 78]. For pancreatic juice, Suenaga et al. (2018) [60] found GNAS gene mutations in $70 \%$ of patients with IPMN. Also, TP53 and SMAD-4 levels were found to be related to dysplasia grade, and able to distinguish IPMN from PDAC with a sensitivity and specificity of 32 and $100 \%$, respectively $[60,79]$. A VHL gene mutation increases the probability of detecting a serous cyst neoplasia (SCN) [60, 79].

Pancreatoscopy uses a thin scope that is introduced in the MPD during ERCP or surgery. It enables intraductal visualisation and image-guided tissue sampling. For differentiation between benign and malignant MDIPMN, the accuracy is relatively high $(88 \%)$, yet also are the rates of post- 
procedural pancreatitis (7\%) [80]. During surgery, pancreatoscopy may be combined with intraductal frozen biopsies, to assess the extent of MPD involvement and guide resection $[10 \bullet, 81]$.

Needle-based confocal laser endomicroscopy (nCLE) uses a small probe $(0.85 \mathrm{~mm})$ that is placed in a pancreatic cyst via a 19-gauge FNA needle and provides a real-time microscopic view (width $320 \mu \mathrm{m}$, resolution $3.5 \mu \mathrm{m}$ ). It is able to detect a pancreatic cystic neoplasm with a sensitivity of $59-80 \%$ and a specificity of $100 \%$. However, it is currently discouraged by the EU guidelines due to high adverse event rates (7-9\%) [10•, 82-85].

\section{Clinical strategy and surveillance}

\section{Surveillance}

Nowadays, surveillance is recommended in patients with (operated) pancreatic cysts suspected for MCN or IPMN. The best utility and manner of surveillance have not been established. At present, surveillance is based on consensus guidelines, namely the International Association of Pancreatology (IAP; 'Fukuoka guidelines') $[4 \bullet, 5 \bullet, 6 \bullet]$, American College of Gastroenterology (ACG) [7•], American Gastroenterological Association (AGA) [8•] and European Study

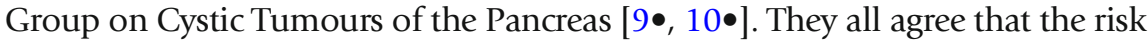
of malignancy should be weighed against life expectancy and co-morbidity. Confusingly, the recommended surveillance strategies differ between guidelines (Table 3). Incentive large-scale prospective registries of individuals undergoing cyst surveillance (e.g. PACYFIC-registry; www.pacyfic.net) are needed to accumulate unbiased data and develop evidence-based guidelines.

According to all guidelines, the presence of mural nodules or solid components is most predictive for malignant disease. Mural nodules are present in 36$70 \%$ of IPMN patients with invasive disease and the size of the mural nodule is correlated with the risk of malignancy $[13,20,31,86]$. Additionally, a thickened cyst wall is present in 65\% of patients with invasive disease (OR 4.80; 95\% CI 1.16-14.36) [13, 87]. In case of doubt, contrast-harmonic endoscopic ultrasound (CH-EUS) helps to differentiate between mucin and a solid component by the presence of small blood vessels in the latter.

Although cyst size is associated with invasiveness, treatment should not be determined by size alone, since small cysts do not exclude invasiveness and large cysts do not always harbour malignancy $[18,19,88-90]$. The surveillance intervals in both Fukuoka and ACG guidelines are based on cyst size in the absence of a more practical surrogate $[6 \bullet, 7 \bullet]$. The cyst growth appears to be more predictive. A growth of $>2 \mathrm{~mm} /$ year is related to a $45 \% 5$-year risk of developing malignancy versus $1.8 \%$ in slowly growing cysts [96-98]. Due to a recorded size difference between the different imaging modalities, it is recommended not to alternate modalities between follow-up visits [7•, 10•, 87, 94].

The mean MPD diameter is significantly larger in patients with malignant disease. Some guidelines use a 10-mm cut-off value, as absolute indication for surgery $[6 \bullet, 10 \bullet]$. This is disputable, since the risk of malignancy is already increased to $59 \%$ for patients with a pancreatic duct width between 5 and $9 \mathrm{~mm}$ [22]. The AGA and ACG guidelines recommend EUS-FNA in cysts associated with a dilated MPD (ACG cut-off $>5 \mathrm{~mm}$, AGA non-specified) $[7 \bullet, 8 \bullet, 17,19,22,95]$. 
Table 3. An overview of four most recent guidelines on diagnosis and management of pancreatic cystic neoplasms [6, 8, 10, 95]

\begin{tabular}{|c|c|c|c|c|}
\hline & $\begin{array}{l}\text { Revised EU guideline } \\
(2018)\end{array}$ & $\begin{array}{l}\text { Revised Fukuoka } \\
\text { guideline (2017) }\end{array}$ & ACG guideline (2018) & AGA guideline (2015) \\
\hline Diagnostic work-up & $\begin{array}{l}\text { MRI: } 1^{\text {st }} \text { choice } \\
\text { CT: } 2^{\text {nd }} \text { choice* }^{*} \\
\text { EUS: supplementary } \\
\text { FNA: in case of mural } \\
\text { nodules, septations } \\
\text { or indefinite imaging } \\
\text { Serum } 19-9\end{array}$ & $\begin{array}{l}\text { MRI: } 1^{\text {st }} \text { choice } \\
\text { CT: } 2^{\text {nd }} \text { choice* } \\
\text { EUS: for worrisome features } \\
\text { FNA: in case of } \\
\text { indefinite imaging; } \\
\text { discouraged } \\
\text { in case of high-risk/ } \\
\text { worrisome features } \\
\text { Serum } 19-9\end{array}$ & $\begin{array}{l}\text { MRI: } 1^{\text {st }} \text { choice } \\
\text { EUS/CT: alternative } \\
\text { FNA: in case of } \\
\text { indefinite imaging, } \\
\text { high risk characteristics, } \\
\text { cysts }>2 \mathrm{~cm} \\
\text { (differentiation } \\
\text { mucinous and } \\
\text { non-mucinous) } \\
\text { Serum } 19-9\end{array}$ & $\begin{array}{l}\text { MRI: } 1^{\text {st }} \text { choice } \\
\text { EUS: high-risk features } \\
\text { FNA: in case of } \geq 2 \\
\text { high-risk features or } \\
\text { significant change of } \\
\text { high-risk feature }\end{array}$ \\
\hline $\begin{array}{l}\text { MD-/MT-IPMN: } \\
\text { indications } \\
\text { for surgery }\end{array}$ & Surgically fit patients & $\begin{array}{l}\text { Surgically fit and } \geq \\
1 \text { high-risk stigmata } \\
\text { (see below) }\end{array}$ & $\begin{array}{l}\text { Reference to } \\
\text { multidisciplinary } \\
\text { group in case of } \\
\text { main-duct } \\
\text { involvement }\end{array}$ & Not mentioned \\
\hline $\begin{array}{l}\text { BD-IPMN: high-risk } \\
\text { features/indications } \\
\text { surgery }\end{array}$ & $\begin{array}{l}\text { Absolute indications: } \\
\text { Solid mass } \\
\text { Enhancing mural } \\
\text { nodule } \geq 5 \mathrm{~mm} \\
\text { MPD } \geq 10 \mathrm{~mm} \\
\text { HGD/carcinoma in cytology } \\
\text { Jaundice } \\
\text { Relative indications: } \\
\text { Cyst growth } \geq 5 \mathrm{~mm} / \text { year } \\
\text { Cyst size } \geq 4 \mathrm{~cm} \\
\text { Enhancing mural } \\
\text { nodule }<5 \mathrm{~mm} \\
\text { MPD 5-9.9 mm } \\
\text { Serum CA } 19-9 \geq 37 \mathrm{U} / \mathrm{ml} \\
\text { New-onset DM } \\
\text { Acute pancreatitis }\end{array}$ & $\begin{array}{l}\text { High-risk stigmata: } \\
\text { Enhancing mural } \\
\text { nodule }>5 \mathrm{~mm} \\
\text { MPD }>10 \mathrm{~mm} \\
\text { Jaundice } \\
\text { Worrisome features: } \\
\text { Growth } \geq 5 \mathrm{~mm} / 2 \text { years } \\
\text { Cyst size } \geq 3 \mathrm{~cm} \\
\text { Enhancing mural } \\
\text { nodule }<5 \text { mm } \\
\text { Enhancing thickened } \\
\text { cyst wall } \\
\text { MPD } 5-9 \text { mm } \\
\text { PD calibre change } \\
\text { Elevated serum CA 19-9 } \\
\text { Pancreatitis }\end{array}$ & $\begin{array}{l}\text { High-risk characteristics: } \\
\text { Mural nodule/solid } \\
\text { component } \\
\text { MPD }>5 \mathrm{~mm} \\
\text { PD calibre change } \\
+ \text { atrophy } \\
\text { Cyst size } \geq 3 \mathrm{~mm} \\
\text { Cyst growth }>3 \mathrm{~mm} / \text { year } \\
\text { HGD/carcinoma in cytology } \\
\text { Jaundice } \\
\text { Acute pancreatitis } \\
\text { Elevated serum CA 19-9 } \\
\text { New-onset DM }\end{array}$ & $\begin{array}{l}\text { High-risk features: } \\
\text { Solid component } \\
\text { Dilated MPD } \\
\text { Cyst size } \geq 3 \mathrm{~cm}\end{array}$ \\
\hline Duration surveillance & As long as fit for surgery & $\begin{array}{l}\text { As long as fit for } \\
\text { surgery }\end{array}$ & $\begin{array}{l}\text { As long as fit for surgery } \\
\text { Individualized approach } \\
\text { for age } 76-85 \text { years }\end{array}$ & $\begin{array}{l}\text { Discontinue after } 5 \text { years } \\
\text { if no significant change has } \\
\text { occurred }\end{array}$ \\
\hline Surveillance intervals & $\begin{array}{l}6 \text { months ( } 1^{\text {st }} \text { year), then } \\
\text { yearly }\end{array}$ & $\begin{array}{l}<1 \mathrm{~cm}: 6 \text { months, } \\
\text { then } 2 \text { yearly } \\
1-2 \mathrm{~cm}: 6 \text { months } \\
\left(1^{\text {st }} \text { year }\right) \text {, yearly } \\
(2 \text { years }) \text {, then } 2 \text { yearly } \\
2-3 \mathrm{~cm}: 3-6 \text { months } \\
\left(1^{\text {st }} \text { year }\right) \text {, then yearly } \\
>3 \mathrm{~cm}: 3-6 \text { months }\end{array}$ & $\begin{array}{l}<1 \mathrm{~cm}: 2 \text { years } \\
1-2 \mathrm{~cm}: 1 \text { year } \\
2-3 \mathrm{~cm} \text {, clear IPMN/MCN: } \\
6-23 \text { months. } \\
\text { Shorter interval for } \\
\text { new-onset } \\
\text { DM or cyst growth }>3 \\
\mathrm{~mm} / \text { year }\end{array}$ & At years 1,3 and 5 \\
\hline Indication for surgery & $\begin{array}{l}\geq 1 \text { Absolute indication } \\
\geq 1 \text { Relative indication } \\
\text { without significant } \\
\text { co-morbidities } \\
\geq 2 \text { Relative indications } \\
\text { for patients with significant } \\
\text { co-morbidities }\end{array}$ & $\begin{array}{l}\geq 1 \text { High risk } \\
\text { stigmata } \\
\geq 1 \text { Worrisome feature } \\
\text { and } \geq 1 \text { of the following: } \\
\text { Definite mural nodule, } \\
\text { MPD involvement } \\
\text { Suspect cytology } \\
\text { Consider: cyst }>2 \mathrm{~cm} \\
\text { in young and fit patient }\end{array}$ & $\begin{array}{l}\text { Decided by } \\
\text { multidisciplinary } \\
\text { team. Referral in case of } \\
\text { jaundice or } \geq 1 \text { of the } \\
\text { following: MPD }>5 \mathrm{~mm} \text {, } \\
\text { Cyst size } \geq 3 \mathrm{~mm} \\
\text { Calibre change MPD } \\
\text { MPD involvement } \\
\text { HGD/PDAC cytology } \\
\text { Mural nodule }\end{array}$ & $\begin{array}{l}\text { Solid component and } \\
\text { dilated MPD and/or } \\
\text { concerning features } \\
\text { on EUS-FNA }\end{array}$ \\
\hline $\begin{array}{l}\text { Surveillance after } \\
\text { resection }\end{array}$ & $\begin{array}{l}\text { Malignancy: according } \\
\text { to PDAC guidelines }\end{array}$ & $\begin{array}{l}\text { Malignancy: } \\
\text { according to } \\
\text { PDAC quideline }\end{array}$ & $\begin{array}{l}\text { Malignancy: according to } \\
\text { PDAC guidelines } \\
\text { HGD: every } 6 \text { months }\end{array}$ & $\begin{array}{l}\text { Dysplasia/malignancy: } \\
\text { every } 2 \text { years }\end{array}$ \\
\hline
\end{tabular}


Table 3. (continued)

\begin{tabular}{|c|c|c|c|}
\hline $\begin{array}{l}\text { Revised EU guideline } \\
\text { (2018) }\end{array}$ & $\begin{array}{l}\text { Revised Fukuoka } \\
\text { guideline (2017) }\end{array}$ & ACG guideline (2018) & AGA guideline (2015) \\
\hline $\begin{array}{l}\text { HGD/MD-IPMN: } 6 \text { months } \\
\left(1^{\text {st }} 2 \text { years), then yearly }\right. \\
\text { LGD: as non-operated }\end{array}$ & $\begin{array}{l}2 x / \text { year in case of one } \\
\text { of the following: family } \\
\text { history of PDAC, surgical } \\
\text { margin with HGD, } \\
\text { non-intestinal type IPMN } \\
\text { Other patients Every } \\
6-12 \text { months }\end{array}$ & $\begin{array}{l}\text { Low-/intermediate grade } \\
\text { dysplasia: every } 2 \text { years }\end{array}$ & $\begin{array}{l}\text { If not: no FU (unless } \\
\text { MT-IPMN or family } \\
\text { history of PDAC) }\end{array}$ \\
\hline
\end{tabular}

EU, European; ACG, American College of Gastroenterology; AGA, American Gastroenterological Association; MRI, magnetic resonance imaging; CT, computer tomography; EUS, endoscopic ultrasound; FNA, fine-needle aspiration; CH-EUS, contrast-enhanced harmonic EUS; CA 19-9, cancer antigen 19-9; DM, diabetes mellitus; FU, follow-up; PDAC, pancreatic ductal adenocarcinoma; LGD, low-grade dysplasia; HGD, high-grade dysplasia *To identify calcifications, for tumour staging or for surveillance of recurrence in case of PDAC

According to the EU, Fukuoka and ACG guidelines, the duration of surveillance should be lifelong. The AGA guideline recommends stopping surveillance in the case of a stable cyst after 5 years. Interestingly, Kwong et al. (2016) [96] found an eightfold higher mortality from non-pancreatic causes than from pancreatic cancer after 5 years of surveillance in low-risk BD-IPMN. On the other hand, multiple studies detected high-risk features in asymptomatic BDIPMN patients after a follow-up period of more than 5 years [97-99]. Additionally, Del Chiaro et al. (2017) [100] found an IPMN-related mortality of 5.8\% after 10 years of follow-up in patients without high-risk features at baseline.

After resection of IPMN, lifelong surveillance is recommended, as long as the patient is able and willing to undergo surgery $[6 \bullet, 7 \bullet, 8 \bullet, 10 \bullet]$. He et al. (2013) [101] estimated the chance of developing a new lesion after resection of noninvasive IPMN at $1.6 \%$ after 1 year, $14 \%$ after 5 years and $18 \%$ after 10 years and the chance of invasive pancreatic cancer 0\% after 1 year, $7 \%$ after 5 years and $38 \%$ after 10 years. For invasive IPMN, post-resection surveillance is recommended solely based on symptoms, similar to pancreatic cancer $[6 \bullet, 10 \bullet]$. However, one could argue that surveillance should restart (e.g. after five years) for patients with early-stage invasive IPMN, surveillance should restart after $\sim 5$ years of survival.

Additionally, data about the incidence of extra-pancreatic neoplasms in patients with IPMN remains controversial, since some retrospective studies show an increased risk in other cancers (e.g. colorectal and gastric cancer) [102-105]. A large study of 1340 patients by Marchegiani et al. (2015) [36] did not find a higher incidence of extra-pancreatic neoplasms in patients with IPMN. Guidelines do not recommend additional imaging (e.g. CT) for surveillance of extrapancreatic malignancies in patients with $\operatorname{IPMN}[6 \bullet, 7 \bullet, 8 \bullet, 10 \bullet]$.

Guidelines recommend that surgery should be performed by an experienced surgeon in a high-volume centre after consultation and joint decision by a multidisciplinary group with pancreatic expertise. Especially, advanced age and the presence of co-morbidity are related to postoperative mortality of non-pancreatic cause [106-108]. On the other hand, early surgery could be considered in younger patients with no comorbidity $[9 \bullet, 10 \bullet]$. 
MD-IPMN and MT-IPMN justify a more aggressive treatment approach than BD-IPMN. In general, surgery should be offered as this is justified by the high prevalence of invasive disease (MD-IPMN 11-81\%; MT 20-65\%) and the high disease-specific mortality (23 per 1000 patient years; 95\% CI 12-52) for untreated MD-IPMN and MT-IPMN [109].

For BD-IPMN, the guidelines are inconsistent and compared in Table 3. The Fukuoka guidelines recommend surgery in the case of $\geq 1$ high-risk stigmata or $\geq 1$ worrisome features and one of the following: mural nodule $\geq 5 \mathrm{~mm}$, suspicious MPD, suspicious cytology [6•]. The EU guideline is similar, yet in the case of surgical indication, age and the presence of co-morbidity are advised to be taken into account [10•]. ACG stresses the need of decision-making by a multidisciplinary pancreatic group $[7 \bullet]$.

In case of suspected malignancy, an oncological resection should be performed. For all IPMNs, intraoperative frozen section examination of the resection margins is recommended. For patients with MD-IPMN or MT-IPMN, intraoperative pancreatoscopy with frozen section of intraductal biopsies can be considered $[10 \bullet]$. Patients with positive margins have a worse survival and extended resection is recommended [15]. Cysts in multifocal IPMNs should be approached autonomously due to their distinct behaviour; the most suspicious lesion(s) should be removed. A total pancreatectomy is only recommended in the case of multiple worrisome features throughout the pancreas or post-surgical recurrence in the remnant pancreas and is performed in 3-37\% of the patients. Severe weight loss, diarrhoea (exocrine insufficiency) and/or hypoglycaemic episodes (i.e. brittle diabetes; endocrine insufficiency) are regular consequences of total pancreatectomy [116 117]. However, the majority experiences severe weight loss, diarrhoea (exocrine insufficiency) and/or hypoglycaemic episodes in relation to brittle diabetes (endocrine insufficiency) [110, 111]. The survival rates of total pancreatectomy after 1 and 3 years are 80 and 65\%, respectively [111].

Pancreaticoduodenectomy ( Whipple procedure) and distal pancreatectomy are performed in $42-70 \%$ and $13-47 \%$ of the cases $[13,15,17,32,118]$. These procedures are related to complications in $25 \%$ of patients, such as anastomotic leakage or stenosis, pancreatic fistula, intra-abdominal abscess, pancreatitis, pancreatic pseudocyst, cholangit is, delayed gastric emptying, ascites, diarrhoea or pneumonia [19]. In-hospital morbidity is 37\%, and the in-hospital and 30day mortality $1.4 \%$ and 2.7 , respectively $[15,119]$.

\section{Prognosis}

Recurrence after surgery

The overall recurrence rate for IPMN is 11-20\% (median 58-73 months), which increases to $65 \%$ in the case of malignant IPMN $[7 \bullet, 24,114,115]$. For BD-IPMN, $\sim 40 \%$ is multifocal, which may explain the frequent early recurrence of IPMN in the remnant pancreas (12.5\%; mean follow-up 28 months) [116]. Additionally, an increased age, BMI, number of resected lesions as well as an initial location in the pancreatic tail, invasiveness and a family history of PDAC are predictors of recurrence or disease progression [117, 118]. The estimated chance to develop a new primary IPMN and related invasive pancreatic cancer after 5 years is 14 and 7\%, respectively [101, 114, 119]. The recurrence rate for MD-IPMN is higher than for BD-IPMN. The dysplasia 
grade in the resection specimen is the most important predictor of the (severity of) recurrence $[24,114,120]$.

A large observational study by Marchegiani et al. (2015) [114] found a 5-year survival after resection of $77 \%$ for all IPMNs, $69 \%$ for MD-IPMN and $82 \%$ for BD-IPMN, with a median time to survival of 17,13 and 24 months, respectively. Vanella et al. (2018) [109] performed a meta-analysis and found a diseasespecific mortality of 23 for all IPMN, 32 for MD-IPMN and 5 for BD-IPMN per 1000 patient years.

In case of invasiveness the overall survival decreases significantly (95\% vs. 49\%)[114]. Low-grade dysplasia exhibits a similar survival as high-grade dysplasia. In the case of invasive disease, the survival is significantly lower. Of all patients with IPMN-associated adenocarcinoma, 53\% has lymph-node metastases, 58\% peri-neural and 33\% vascular invasion [114, 121].

\section{Compliance with Ethical Standards}

\section{Conflict of Interest}

Djuna Cahen is a consultant for Tramedico. Marco Bruno reports grants and personal fees from Boston Scientific, Cook Medical, Pentax, and 3M, outside the submitted work. Iris Levink declares no conflict of interest.

Human and Animal Rights and Informed Consent

This article does not contain any studies with human or animal subjects performed by any of the authors.

Open Access This article is distributed under the terms of the Creative Commons Attribution 4.0 International License (http://creativecommons.org/licenses/by/4.0/), which permits unrestricted use, distribution, and reproduction in any medium, provided you give appropriate credit to the original author(s) and the source, provide a link to the Creative Commons license, and indicate if changes were made.

\section{References and Recommended Reading}

Papers of particular interest, published recently, have been highlighted as:

- Of importance

1. Ohhashi K. Four cases of mucous secreting pancreatic cancer. Prog Dis Endosc. 1982;20:348-51.

2. Sessa F, Solcia E, Capella C, Bonato M, Scarpa A, Zamboni G, et al. Intraductal papillary-mucinous tumours represent a distinct group of pancreatic neoplasms: an investigation of tumour cell differentiation and K-ras, p53 and c-erbB-2 abnormalities in 26 patients. Virchows Arch. 1994;425:357-67.

3. Tulla KA, Maker AV. Can we better predict the biologic behavior of incidental IPMN? A comprehensive analysis of molecular diagnostics and biomarkers in intraductal papillary mucinous neoplasms of the pancreas. Langenbeck's Arch Surg. 2017.

4. Tanaka M, Chari S, Adsay V, Fernandez-del Castillo C, Falconi M, Shimizu M, et al. International consensus guidelines for management of intraductal papillary mucinous neoplasms and mucinous cystic neoplasms of the pancreas. Pancreatology. 2006;6:17-32.

The first multidisciplinary consensus guidelines on the clinical management of pancreatic cysts and defined high-risk features (mural nodule, main-duct dilation, size $>3 \mathrm{~cm}$ ) related to increased risk of malignant progression. 
5. $\quad$ Tanaka M, Fernandez-del Castillo C, Adsay V, et al. International consensus guidelines 2012 for the management of IPMN and MCN of the pancreas.

Pancreatology. 2012;12:183-97.

In response to their publication in 2006, extensive research led to new insights and the dichotomization of risk stratification ('high-risk' and 'worrisome' features). Recommending immediate resection in the case of high-risk features and a conservative approach in the case of worrisome features. Surveillance intervals are based on the the size of the cyst.

6. Tanaka M, Fernandez-Del Castillo C, Kamisawa T, et al. Revisions of international consensus Fukuoka guidelines for the management of IPMN of the pancreas. Pancreatology. 2017;17:738-53.

In 2017, the International Association of Pancreatology performed minor revisions and updates according to recent literature. High-risk stigmata remained the same, yet some worrisome features (e.g. lymphadenopathy, CA19-9 levels and cyst growth rate) were added.

7. $\quad$ Elta GH, Enestvedt BK, Sauer BG, Marie Lennon A. ACG clinical guideline: diagnosis and management of pancreatic cysts. Am J Gastroenterol.

2018;113:464-79.

With the increased quality of imaging modalities and the subsequent prevalent detection of pancreatic cysts came more guidelines. The ACG guidelines used describe 11 high-risk characteristics' of which seven characteristics indicate surgery.

8. Vege SS, Ziring B, Jain R, et al. American Gastroenterological Association Institute guideline on the diagnosis and management of asymptomatic neoplastic pancreatic cysts. Gastroenterology. 2015;148:819-22.

These AGA guidelines defined three high-risk features (solid component in the cyst, dilated MPD and cysts size $\geq 3 \mathrm{~cm}$ ). These guidelines led to discussion due to their recommendation to discontinue surveillance in the case of no significant change of cyst during 5 years follow-up.

9. $\quad$ Del Chiaro M, Verbeke C, Salvia R, et al. European experts consensus statement on cystic tumours of the pancreas. Dig Liver Dis. 2013;45:703-11.

The European respond to the Tanaka guidelines, distingishuing absolute and relative indications for surgery and simplified the surveillance intervals to 6 months in the first year and yearly afterwards.

10. European evidence-based guidelines on pancreatic cystic neoplasms. Gut 2018.

The most recent guidelines, advocating an international workgroup (together with AGA, ACG, IAP) for the publication of one future worldwide guideline.

11. Lee SY, Lee KT, Lee JK, et al. Long-term follow up results of intraductal papillary mucinous tumors of pancreas. J Gastroenterol Hepatol. 2005;20:1379-84.

12. Crippa S, Fernandez-Del Castillo C, Salvia R, et al. Mucin-producing neoplasms of the pancreas: an analysis of distinguishing clinical and epidemiologic characteristics. Clin Gastroenterol Hepatol. 2010;8:213-9.

13. Hwang DW, Jang J-Y, Lee SE, Lim CS, Lee KU, Kim SW. Clinicopathologic analysis of surgically proven intraductal papillary mucinous neoplasms of the pancreas in SNUH: a 15-year experience at a single academic institution. Langenbeck's Arch Surg. 2012;397:93-102.

14. Salvia R, Castillo CF-d, Bassi C, et al. Main-duct intraductal papillary mucinous neoplasms of the pancreas: clinical predictors of malignancy and long-term survival following resection. Ann Surg. 2004;239:678-87.

15. Schnelldorfer T, Sarr MG, Nagorney DM, Zhang L, Smyrk TC, Qin R, et al. Experience with 208 resections for intraductal papillary mucinous neoplasm of the pancreas. Arch Surg. 2008;143:639-46. discussion 646

16. Ohno E, Hirooka Y, Kawashima H, et al. Natural history of pancreatic cystic lesions: a multicenter prospective observational study for evaluating the risk of pancreatic cancer. J Gastroenterol Hepatol. 2017.

17. Kim SC, Park KT, Lee YJ, Lee SS, Seo DW, Lee SK, et al. Intraductal papillary mucinous neoplasm of the pancreas: clinical characteristics and treatment outcomes of 118 consecutive patients from a single center. J HepatoBiliary-Pancreat Surg. 2008;15:183-8.

18. Suzuki Y, Atomi Y, Sugiyama M, Isaji S, Inui K, Kimura $\mathrm{W}$, et al. Cystic neoplasm of the pancreas: a Japanese multiinstitutional study of intraductal papillary mucinous tumor and mucinous cystic tumor. Pancreas. 2004;28:241-6.

19. Nagai K, Doi R, Kida A, et al. Intraductal papillary mucinous neoplasms of the pancreas: clinicopathologic characteristics and long-term follow-up after resection. World J Surg. 2008;32:271-8.

20. Schmidt CM, White PB, Waters JA, Yiannoutsos CT, Cummings OW, Baker $\mathrm{M}$, et al. Intraductal papillary mucinous neoplasms: predictors of malignant and invasive pathology. Ann Surg. 2007;246:644-51. discussion 651-4

21. Yu S, Takasu N, Watanabe T, Fukumoto T, Okazaki S, Tezuka K, et al. Validation of the 2012 Fukuoka consensus guideline for intraductal papillary mucinous neoplasm of the pancreas from a single institution experience. Pancreas. 2017;46:936-42.

22. Abdeljawad K, Vemulapalli KC, Schmidt CM, Dewitt J, Sherman S, Imperiale TF, et al. Prevalence of malignancy in patients with pure main duct intraductal papillary mucinous neoplasms. Gastrointest Endosc. 2014;79:623-9.

23. Fritz S, Klauss M, Bergmann F, Strobel O, Schneider L, Werner J, et al. Pancreatic main-duct involvement in branch-duct IPMNs: an underestimated risk. Ann Surg. 2014;260:848-55. discussion 855-6

24. Kang MJ, Jang JY, Lee KB, Chang YR, Kwon W, Kim SW. Long-term prospective cohort study of patients undergoing pancreatectomy for intraductal papillary mucinous neoplasm of the pancreas: implications for postoperative surveillance. Ann Surg. 2014;260:356-63.

25. Furukawa T, Hatori T, Fujita I, Yamamoto M, Kobayashi M, Ohike N, et al. Prognostic relevance of morphological types of intraductal papillary mucinous neoplasms of the pancreas. Gut. 2011;60:509-16.

26. Shimizu Y, Yamaue H, Maguchi H, Yamao K, Hirono S, Osanai M, et al. Predictors of malignancy in intraductal 
papillary mucinous neoplasm of the pancreas: analysis of 310 pancreatic resection patients at multiple highvolume centers. Pancreas. 2013;42:883-8.

27. Lafemina J, Katabi N, Klimstra D, et al. Malignant progression in IPMN: a cohort analysis of patients initially selected for resection or observation. Ann Surg Oncol. 2013;20:440-7.

28. Koh YX, Zheng HL, Chok AY, Tan CS, Wyone W, Lim $\mathrm{TKH}$, et al. Systematic review and meta-analysis of the spectrum and outcomes of different histologic subtypes of noninvasive and invasive intraductal papillary mucinous neoplasms. Surgery. 2015;157:496-509.

29. Castellano-Megias VM, Andres CI, Lopez-Alonso G, et al. Pathological features and diagnosis of intraductal papillary mucinous neoplasm of the pancreas. World J Gastrointest Oncol. 2014;6:311-24.

30. Furukawa T, Kloppel G, Volkan Adsay N, et al. Classification of types of intraductal papillary-mucinous neoplasm of the pancreas: a consensus study. Virchows Arch. 2005;447:794-9.

31. Ridtitid W, DeWitt JM, Schmidt CM, et al. Management of branch-duct intraductal papillary mucinous neoplasms: a large single-center study to assess predictors of malignancy and long-term outcomes. Gastrointest Endosc. 2016;84:436-45.

32. Aune D, Greenwood DC, Chan DSM, Vieira R, Vieira AR, Navarro Rosenblatt DA, et al. Body mass index, abdominal fatness and pancreatic cancer risk: a systematic review and non-linear dose-response metaanalysis of prospective studies. Ann Oncol. 2012;23:843-52.

33. Smits MM, van Geenen EJ. The clinical significance of pancreatic steatosis. Nat Rev Gastroenterol Hepatol. 2011;8:169-77.

34. Sturm EC, Roch AM, Shaffer KM, Schmidt CM II, Lee SJ, Zyromski NJ, et al. Obesity increases malignant risk in patients with branch-duct intraductal papillary mucinous neoplasm. Surgery. 2013;154:803-8. discussion 808-9

35. Capurso G, Boccia S, Salvia R, et al. Risk factors for intraductal papillary mucinous neoplasm (IPMN) of the pancreas: a multicentre case-control study. Am J Gastroenterol. 2013;108:1003-9.

36. Marchegiani G, Malleo G, D'Haese JG, et al. Association between pancreatic intraductal papillary mucinous neoplasms and extrapancreatic malignancies. Clin Gastroenterol Hepatol. 2015;13:1162-9.

37. Moris M, Raimondo M, Woodward TA, Skinner V, Arcidiacono PG, Petrone MC, et al. Diagnostic accuracy of endoscopic ultrasound-guided fine-needle aspiration cytology, carcinoembryonic antigen, and amylase in intraductal papillary mucinous neoplasm. Pancreas. 2016;45:870-5.

38. Morales-Oyarvide V, Mino-Kenudson M, Ferrone CR, Sahani DV, Pergolini I, Negreros-Osuna AA, et al. Diabetes mellitus in intraductal papillary mucinous neoplasm of the pancreas is associated with high-grade dysplasia and invasive carcinoma. Pancreatology. 2017;17:920-6.
39. Kobayashi G, Fujita N, Noda Y, Ito K, Horaguchi J, Obana $\mathrm{T}$, et al. Intraductal papillary mucinous neoplasms of the pancreas showing fistula formation into other organs. J Gastroenterol. 2010;45:1080-9.

40. Yamada Y, Mori H, Hijiya N, Matsumoto S, Takaji R, Ohta $\mathrm{M}$, et al. Intraductal papillary mucinous neoplasms of the pancreas complicated with intraductal hemorrhage, perforation, and fistula formation: CT and MR imaging findings with pathologic correlation. Abdom Imaging. 2012;37:100-9.

41. Kimura W, Nagai H, Kuroda A, Muto T, Esaki Y. Analysis of small cystic lesions of the pancreas. Int J Pancreatol. 1995;18:197-206.

42. Su Jin S, Jeong Min L, Young Jun K, et al. Differentiation of intraductal papillary mucinous neoplasms from other pancreatic cystic masses: comparison of multirow-detector CT and MR imaging using ROC analysis. J Magn Reson Imaging. 2007;26:86-93.

43. Rastegar N, Matteoni-Athayde LG, Eng J, et al. Incremental value of secretin-enhanced magnetic resonance cholangiopancreatography in detecting ductal communication in a population with high prevalence of small pancreatic cysts. Eur J Radiol. 2015;84:575-80.

44. Harima H, Kaino S, Shinoda S, Kawano M, Suenaga S, Sakaida I. Differential diagnosis of benign and malignant branch duct intraductal papillary mucinous neoplasm using contrast-enhanced endoscopic ultrasonography. World J Gastroenterol. 2015;21:6252-60.

45. Rodriguez-D'Jesus A, Fernandez-Esparrach G, Boadas J, et al. Impact of endoscopic ultrasonography (EUS) and EUS-guided fine-needle aspiration on the management of pancreatic cystic lesions. Eur J Gastroenterol Hepatol. 2016;28:1094-9.

46. Kamata K, Kitano M, Kudo M, Sakamoto H, Kadosaka $\mathrm{K}$, Miyata T, et al. Value of EUS in early detection of pancreatic ductal adenocarcinomas in patients with intraductal papillary mucinous neoplasms. Endoscopy. 2014;46:22-9.

47. Javia S, Munigala S, Guha S, et al. EUS morphology is reliable in selecting patients with mucinous pancreatic cyst(s) most likely to benefit from surgical resection. Gastroenterol Res Pract. 2017;2017:9863952.

48. Lu X, Zhang S, Ma C, Peng C, Lv Y, Zou X. The diagnostic value of EUS in pancreatic cystic neoplasms compared with CT and MRI. Endosc Ultrasound. 2015;4:324-9.

49. van der Waaij LA, van Dullemen HM, Porte RJ. Cyst fluid analysis in the differential diagnosis of pancreatic cystic lesions: a pooled analysis. Gastrointest Endosc. 2005;62:383-9.

50. Suzuki R, Thosani N, Annangi S, Guha S, Bhutani MS. Diagnostic yield of EUS-FNA-based cytology distinguishing malignant and benign IPMNs: a systematic review and meta-analysis. Pancreatology. 2014;14:380-4.

51. Thosani N, Thosani S, Qiao W, Fleming JB, Bhutani MS, Guha S. Role of EUS-FNA based cytology in diagnosis of mucinous pancreatic cystic lesions: a systematic review and meta-analysis. Dig Dis Sci.

2010;55:2756-66. 
52. Rogart JN, Loren DE, Singu BS, Kowalski TE. Cyst wall puncture and aspiration during EUS-guided fine needle aspiration may increase the diagnostic yield of mucinous cysts of the pancreas. J Clin Gastroenterol. 2011;45:164-9.

53. Siddiqui AA, Shahid H, Shah A, Loren DE, Laique S, Eloubeidi MA, et al. High risk of acute pancreatitis after endoscopic ultrasound-guided fine needle aspiration of side branch intraductal papillary mucinous neoplasms. Endoscopic Ultrasound. 2015;4:109-14.

54. O'Toole D, Palazzo L, Arotçarena R, Dancour A, Aubert A, Hammel P, et al. Assessment of complications of EUS-guided fine-needle aspiration. Gastrointest Endosc. 2001;53:470-4.

55. Hong S-KS, Loren DE, Rogart JN, Siddiqui AA, Sendecki JA, Bibbo M, et al. Targeted cyst wall puncture and aspiration during EUS-FNA increases the diagnostic yield of premalignant and malignant pancreatic cysts. Gastrointest Endosc. 2012;75:775-82.

56. Yoon WJ, Brugge WR. The safety of endoscopic ultrasound-guided fine-needle aspiration of pancreatic cystic lesions. Endoscopic Ultrasound. 2015;4:289-92.

57. Polkowski M, Larghi A, Weynand B, Boustière C, Giovannini M, Pujol B, et al. Learning, techniques, and complications of endoscopic ultrasound (EUS)-guided sampling in gastroenterology: European Society of Gastrointestinal Endoscopy (ESGE) technical guideline. Endoscopy. 2012;44:190-206.

58. Hirono S, Tani M, Kawai M, Okada KI, Miyazawa M, Shimizu A, et al. The carcinoembryonic antigen level in pancreatic juice and mural nodule size are predictors of malignancy for branch duct type intraductal papillary mucinous neoplasms of the pancreas. Ann Surg. 2012;255:517-22.

59. Springer S, Wang Y, Dal Molin M, Masica DL, Jiao Y, Kinde I, et al. A combination of molecular markers and clinical features improve the classification of pancreatic cysts. Gastroenterology. 2015;149:1501-10.

60. Suenaga M, Yu J, Shindo K, Tamura K, Almario JA, Zaykoski C, et al. Pancreatic juice mutation concentrations can help predict the grade of dysplasia in patients undergoing pancreatic surveillance. Clin Cancer Res. 2018;24:2963-74.

61. Jian S, William RB, Christopher JD, et al. Molecular analysis of pancreatic cyst fluid. Cancer Cytopathology. 2009;117:217-27.

62. Brugge WR, Lewandrowski K, Lee-Lewandrowski E, et al. Diagnosis of pancreatic cystic neoplasms: a report of the cooperative pancreatic cyst study. Gastroenterology. 2004;126:1330-6.

63. Oh HC, Kang H, Brugge WR. Cyst fluid amylase and CEA levels in the differential diagnosis of pancreatic cysts: a single-center experience with histologically proven cysts. Dig Dis Sci. 2014;59:3111-6.

64. Rabie ME, El Hakeem I, Al Skaini MS, et al. Pancreatic pseudocyst or a cystic tumor of the pancreas? Chinese Journal of Cancer. 2014;33:87-95.

65. Kim YH, Saini S, Sahani D, Hahn PF, Mueller PR, Auh $\mathrm{YH}$. Imaging diagnosis of cystic pancreatic lesions: pseudocyst versus nonpseudocyst. RadioGraphics. 2005;25:671-85.

66. Costa WL, Mantoan H, Brito RH, Ribeiro H, Diniz AL, Godoy A, et al. Pancreatic mucinous cystadenoma with serum CA 19-9 over 1,000,000 U/mL: a case report and review of the literature. World Journal of Surgical Oncology. 2015;13:78.

67. Gold DV, Gaedcke J, Ghadimi BM, Goggins M, Hruban $\mathrm{RH}$, Liu M, et al. PAM4 immunoassay alone and in combination with CA19-9 for the detection of pancreatic adenocarcinoma. Cancer. 2013;119:522-8.

68. Safi F, Schlosser W, Falkenreck S, Beger HG. Prognostic value of CA 19-9 serum course in pancreatic cancer. Hepatogastroenterology. 1998;45:253-9.

\section{Wang W, Zhang L, Chen L, et al. Serum} carcinoembryonic antigen and carbohydrate antigen 19-9 for prediction of malignancy and invasiveness in intraductal papillary mucinous neoplasms of the pancreas: a meta-analysis. Biomed Rep. 2015;3:43-50.

70. Jae Ri K, Jin-Young J, Mee Joo K, et al. Clinical implication of serum carcinoembryonic antigen and carbohydrate antigen 19-9 for the prediction of malignancy in intraductal papillary mucinous neoplasm of pancreas. Journal of Hepato-Biliary-Pancreatic Sciences. 2015;22:699-707.

71. Wu J, Matthaei H, Maitra A, Dal Molin M, Wood LD, Eshleman JR, et al. Recurrent GNAS mutations define an unexpected pathway for pancreatic cyst development. Sci Transl Med. 2011;3:92ra66.

72. Eliana A, Marco dal M, Andrea M, et al. Targeted nextgeneration sequencing of cancer genes dissects the molecular profiles of intraductal papillary neoplasms of the pancreas. J Pathol. 2014;233:217-27.

73. Hosoda W, Sasaki E, Murakami Y, Yamao K, Shimizu Y, Yatabe Y. GNAS mutation is a frequent event in pancreatic intraductal papillary mucinous neoplasms and associated adenocarcinomas. Virchows Arch. 2015;466:665-74.

74. Lee JH, Kim Y, Choi JW, Kim YS. KRAS, GNAS, and RNF43 mutations in intraductal papillary mucinous neoplasm of the pancreas: a meta-analysis. Springerplus. 2016;5:1172.

75. Molin MD, Matthaei H, Wu J, et al. Clinicopathological correlates of activating GNAS mutations in intraductal papillary mucinous neoplasm (IPMN) of the pancreas. Ann Surg Oncol. 2013;20:3802-8.

76. Kanda M, Matthaei H, Wu J, Hong S-M, Yu J, Borges M, et al. Presence of somatic mutations in most early-stage pancreatic intraepithelial neoplasia. Gastroenterology. 2012;142:730-733.e9.

77. Berger AW, Schwerdel D, Costa IG, et al. Detection of hot-spot mutations in circulating cell-free DNA from patients with intraductal papillary mucinous neoplasms of the pancreas. Gastroenterology. 2016;151:267-70.

78. Yang S, Che SP, Kurywchak P, et al. Detection of mutant KRAS and TP53 DNA in circulating exosomes from healthy individuals and patients with pancreatic cancer. Cancer Biol Ther. 2017;18:158-65. 
79. Yu J, Sadakari Y, Shindo K, Suenaga M, Brant A, Almario JAN, et al. Digital next-generation sequencing identifies low-abundance mutations in pancreatic juice samples collected from the duodenum of patients with pancreatic cancer and intraductal papillary mucinous neoplasms. Gut. 2017;66:1677-87.

80. Hara T, Yamaguchi T, Ishihara T, Tsuyuguchi T, Kondo $\mathrm{F}$, Kato $\mathrm{K}$, et al. Diagnosis and patient management of intraductal papillary-mucinous tumor of the pancreas by using peroral pancreatoscopy and intraductal ultrasonography. Gastroenterology. 2002;122:34-43.

81. Navez J, Hubert C, Gigot J-F, et al. Impact of intraoperative pancreatoscopy with intraductal biopsies on surgical management of intraductal papillary mucinous neoplasm of the pancreas. J Am Coll Surg. 221:982-7.

82. Konda VJ, Meining A, Jamil LH, Giovannini M, Hwang $\mathrm{JH}$, Wallace $\mathrm{MB}$, et al. A pilot study of in vivo identification of pancreatic cystic neoplasms with needle-based confocal laser endomicroscopy under endosonographic guidance. Endoscopy. 2013;45:1006-13.

83. Nakai Y, Iwashita T, Park DH, Samarasena JB, Lee JG, Chang KJ. Diagnosis of pancreatic cysts: EUS-guided, through-the-needle confocal laser-induced endomicroscopy and cystoscopy trial: DETECT study. Gastrointest Endosc. 2015;81:1204-14.

84. Le Pen C, Palazzo L, Napoleon B. A health economic evaluation of needle-based confocal laser endomicroscopy for the diagnosis of pancreatic cysts. Endosc Int Open. 2017;5:E987-95.

85. Napoleon B, Lemaistre AI, Pujol B, et al. A novel approach to the diagnosis of pancreatic serous cystadenoma: needle-based confocal laser endomicroscopy. Endoscopy. 2015;47:26-32.

86. Marchegiani G, Andrianello S, Borin A, Dal Borgo C, Perri G, Pollini T, et al. Systematic review, meta-analysis, and a high-volume center experience supporting the new role of mural nodules proposed by the updated 2017 international guidelines on IPMN of the pancreas. Surgery. 2018;163:1272-9.

87. Maimone S, Agrawal D, Pollack MJ, Wong RCK, Willis $\mathrm{J}$, Faulx AL, et al. Variability in measurements of pancreatic cyst size among EUS, CT, and magnetic resonance imaging modalities. Gastrointest Endosc. 2010;71:945-50.

88. Walsh RM, Vogt DP, Henderson JM, Hirose KZ, Mason $\mathrm{T}$, Bencsath K, et al. Management of suspected pancreatic cystic neoplasms based on cyst size. Surgery. 2008;144:677-84. discussion 684-5

89. Jang JY, Kim SW, Lee SE, Yang SH, Lee KU, Lee YJ, et al. Treatment guidelines for branch duct type intraductal papillary mucinous neoplasms of the pancreas: when can we operate or observe? Ann Surg Oncol. 2008;15:199-205.

90. Weinberg BM, Spiegel BM, Tomlinson JS, et al. Asymptomatic pancreatic cystic neoplasms: maximizing survival and quality of life using Markov-based clinical nomograms. Gastroenterology. 2010;138:531-40.

91. Rautou PE, Levy P, Vullierme MP, et al. Morphologic changes in branch duct intraductal papillary mucinous neoplasms of the pancreas: a midterm follow-up study. Clin Gastroenterol Hepatol. 2008;6:807-14.

92. Kang MJ, Jang JY, Kim SJ, et al. Cyst growth rate predicts malignancy in patients with branch duct intraductal papillary mucinous neoplasms. Clin Gastroenterol Hepatol. 2011;9:87-93.

93. Kwong WT, Lawson RD, Hunt G, Fehmi SM, Proudfoot $\mathrm{JA}, \mathrm{Xu} \mathrm{R}$, et al. Rapid growth rates of suspected pancreatic cyst branch duct intraductal papillary mucinous neoplasms predict malignancy. Dig Dis Sci. 2015;60:2800-6.

94. Boos J, Brook A, Chingkoe CM, Morrison T, Mortele K, Raptopoulos V, et al. MDCT vs. MRI for incidental pancreatic cysts: measurement variability and impact on clinical management. Abdominal Radiology. 2017;42:521-30.

95. Hackert T, Fritz S, Klauss M, Bergmann F, Hinz U, Strobel $\mathrm{O}$, et al. Main-duct intraductal papillary mucinous neoplasm: high cancer risk in duct diameter of 5 to $9 \mathrm{~mm}$. Ann Surg. 2015;262:875-81.

96. Kwong WT, Hunt GC, Fehmi SM, Honerkamp-Smith $\mathrm{G}, \mathrm{Xu} \mathrm{R}$, Lawson RD, et al. Low rates of malignancy and mortality in asymptomatic patients with suspected neoplastic pancreatic cysts beyond 5 years of surveillance. Clin Gastroenterol Hepatol. 2016;14:865-71.

97. Khannoussi W, Vullierme MP, Rebours V, Maire F, Hentic O, Aubert A, et al. The long term risk of malignancy in patients with branch duct intraductal papillary mucinous neoplasms of the pancreas. Pancreatology. 2012;12:198-202.

98. Tanno S, Nakano Y, Nishikawa T, Nakamura K, Sasajima J, Minoguchi M, et al. Natural history of branch duct intraductal papillary-mucinous neoplasms of the pancreas without mural nodules: long-term follow-up results. Gut. 2008;57:339-43.

99. Farrell JJ, Fernández-del Castillo C. Pancreatic cystic neoplasms: management and unanswered questions. Gastroenterology. 2013;144:1303-15.

100. Del Chiaro M, Ateeb Z, Hansson MR, et al. Survival analysis and risk for progression of intraductal papillary mucinous neoplasia of the pancreas (IPMN) under surveillance: a single-institution experience. Ann Surg Oncol. 2017;24:1120-6.

101. He J, Cameron JL, Ahuja N, et al. Is it necessary to follow patients after resection of a benign pancreatic intraductal papillary mucinous neoplasm? J Am Coll Surg. 2013;216:657-65.

102. Larghi A, Panic N, Capurso G, Leoncini E, Arzani D, Salvia R, et al. Prevalence and risk factors of extrapancreatic malignancies in a large cohort of patients with intraductal papillary mucinous neoplasm (IPMN) of the pancreas. Ann Oncol. 2013;24:1907-11.

103. Kato T, Alonso S, Noda H, et al. Malignant, but not benign, intraductal papillary mucinous neoplasm preferentially associates with prior extrapancreatic malignancies. Oncol Rep. 2016;35:3236-40.

104. Roch AM, Rosati CM, Cioffi JL, Ceppa EP, DeWitt JM, al-Haddad MA, et al. Intraductal papillary mucinous 
neoplasm of the pancreas, one manifestation of a more systemic disease? Am J Surg. 2016;211:512-8.

105. Baiocchi GL, Molfino S, Frittoli B, Pigozzi G, Gheza F, Gaverini $\mathrm{G}$, et al. Increased risk of second malignancy in pancreatic intraductal papillary mucinous tumors: review of the literature. World J Gastroenterol. 2015;21:7313-9.

106. de Wilde RF, Besselink MG, van der Tweel I, et al. Impact of nationwide centralization of pancreaticoduodenectomy on hospital mortality. Br J Surg. 2012;99:404-10.

107. Kawakubo K, Tada M, Isayama H, et al. Diseasespecific mortality among patients with intraductal papillary mucinous neoplasm of the pancreas. Clin Gastroenterol Hepatol. 2014;12:486-91.

108. Reames BN, Ghaferi AA, Birkmeyer JD, Dimick JB. Hospital volume and operative mortality in the modern era. Ann Surg. 2014;260:244-51.

109. Vanella G, Crippa S, Archibugi L, Arcidiacono PG, Delle Fave G, Falconi M, et al. Meta-analysis of mortality in patients with high-risk intraductal papillary mucinous neoplasms under observation. Br J Surg. 2018;105:328-38.

110. Maker AV, Sheikh R, Bhagia V. Perioperative management of endocrine insufficiency after total pancreatectomy for neoplasia. Langenbeck's Arch Surg. 2017;402:873-83.

111. Stauffer JA, Nguyen JH, Heckman MG, Grewal MS, Dougherty M, Gill KRS, et al. Patient outcomes after total pancreatectomy: a single centre contemporary experience. HPB : The Official Journal of the International Hepato Pancreato Biliary Association. 2009;11:483-92.

112. Waters JA, Schmidt CM, Pinchot JW, White PB, Cummings OW, Pitt HA, et al. CT vs MRCP: optimal classification of IPMN type and extent. J Gastrointest Surg. 2008;12:101-9.

113. Gleeson EM, Shaikh MF, Shewokis PA, Clarke JR, Meyers WC, Pitt HA, et al. WHipple-ABACUS, a simple, validated risk score for 30-day mortality after pancreaticoduodenectomy developed using the ACSNSQIP database. Surgery. 2016;160:1279-87.
114. Marchegiani G, Mino-Kenudson M, Ferrone CR, Morales-Oyarvide $\mathrm{V}$, Warshaw AL, Lillemoe KD, et al. Patterns of recurrence after resection of IPMN: who, when, and how? Ann Surg. 2015;262:1108-14.

115. Miller JR, Meyer JE, Waters JA, al-Haddad M, DeWitt J, Sherman S, et al. Outcome of the pancreatic remnant following segmental pancreatectomy for non-invasive intraductal papillary mucinous neoplasm. HPB : The Official Journal of the International Hepato Pancreato Biliary Association. 2011;13:759-66.

116. Yan L, Siddiqui AA, Laique SN, Saumoy M, Kahaleh $\mathrm{M}$, Yoo J, et al. A large multicenter study of recurrence after surgical resection of branch-duct intraductal papillary mucinous neoplasm of the pancreas. Minerva Gastroenterol Dietol. 2017;63:50-4.

117. Al Efishat M, Attiyeh MA, Eaton AA, et al. Progression patterns in the remnant pancreas after resection of non-invasive or micro-invasive intraductal papillary mucinous neoplasms (IPMN). Ann Surg Oncol. 2018.

118. Raut CP, Cleary KR, Staerkel GA, Abbruzzese JL, Wolff $\mathrm{RA}$, Lee JH, et al. Intraductal papillary mucinous neoplasms of the pancreas: effect of invasion and pancreatic margin status on recurrence and survival. Ann Surg Oncol. 2006;13:582-94.

119. Fujii T, Kato K, Kodera Y, et al. Prognostic impact of pancreatic margin status in the intraductal papillary mucinous neoplasms of the pancreas. Surgery. 2010;148:285-90.

120. Tamura K, Ohtsuka T, Ideno N, Aso T, Shindo K, Aishima S, et al. Treatment strategy for main duct intraductal papillary mucinous neoplasms of the pancreas based on the assessment of recurrence in the remnant pancreas after resection: a retrospective review. Ann Surg. 2014;259:360-8.

121. Rezaee N, Barbon C, Zaki A, et al. Intraductal papillary mucinous neoplasm (IPMN) with high-grade dysplasia is a risk factor for the subsequent development of pancreatic ductal adenocarcinoma. HPB. 2016;18:236-46. 